\title{
触 New Disease Reports \\ First report of cassava brown streak disease and associated Ugandan cassava brown streak virus in Mayotte Island
}

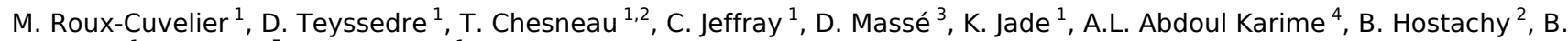
Reynaud $^{1}$, J.P. Legg ${ }^{5}$ and J.M. Lett ${ }^{1 *}$

${ }^{1}$ CIRAD, UMR PVBMT, Pôle de Protection des Plantes, 97410 Saint-Pierre, La Réunion, France; ${ }^{2}$ Lycée Agricole Professionnel de Coconi, BP 02, 97670 Coconi, Mayotte, France; ${ }^{3}$ ANSES-LSV Réunion, Pôle de Protection des Plantes, 97410 Saint-Pierre, La Réunion, France; ${ }^{4}$ DAAF Mayotte, Service de l'Alimentation - Santé des végétaux, BP 103,97600 Mamoudzou, Mayotte, France; ${ }^{5}$ International Institute of Tropical Agriculture, PO Box 34441, Dar es Salaam, Tanzania

*E-mail: lett@cirad.fr

Received: 06 Oct 2014. Published: 07 Dec 2014. Keywords: Cassava brown streak virus, Comoros, southwest Indian Ocean Islands

In November 2013, symptoms of yellowing on leaves and brown necrotic rot on tuberous roots (Fig. 1) were observed on different cassava landraces (Manihot esculenta) in Dembeni on Mayotte Island, a French Overseas Department in the southwest Indian Ocean. The symptoms, similar to the cassava brown streak disease described in East Africa, suggested the possible involvement of cassava brown streak viruses (Mbanzibwa et al., 2011). The expanding cassava brown streak disease epidemic in East Africa is caused by two ipomoviruses, Cassava brown streak virus (CBSV; Monger et al., 2010) and Ugandan cassava brown streak virus (UCBSV; Winter et $a l ., 2010)$. To verify the identity of the causal agent, symptom-bearing leaf samples of 17 affected plants were collected in March and June 2014.

Total RNA was extracted from these samples using the RNeasy Plant Mini Kit (Qiagen, France). For the detection of cassava brown streak viruses, a two-step RT-PCR using CBSDDF2 and CBSDDR primers was used (Mbanzibwa et al., 2011). These primers were designed for simultaneous virus-specific detection of CBSV and UCBSV (amplicons of $344 \mathrm{bp}$ and $440 \mathrm{bp}$, respectively). RT-PCR products of the expected size for UCBSV were obtained for 11 samples. To confirm the diagnosis, the RT-PCR products were directly and bi-directionally sequenced and contigs assembled using DNABaser (Heracle BioSoft, Romania). Sequences of 376 bp from eight of the 11 samples were obtained which had 99-100\% nucleotide identity (MEGA6; Tamura et al., 2013) (EMBL Accession Nos. LN611671 to LN611678; Table 1). The sequences showed the highest nucleotide identity $(86 \%)$ with isolates of UCBSV from Uganda and Malawi (FN434109; FN433932) and 85\% with an isolate of CBSV from Mozambique (FN434436). A phylogenetic reconstruction with publicly available complete genome sequences of cassava brown streak viruses confirmed that the Mayotte isolates are genetically more related to UCBSV isolates than to CBSV isolates from East Africa, and represent a separate lineage that appears to be almost intermediate between current isolates of CBSV and UCBSV (MEGA6; Fig. 2). This is the first report of cassava brown streak disease in Mayotte. Given that cassava is a staple food in the
Comoros archipelago and Madagascar, this report is of great significance for managing the health of cassava in this region, and warrants urgent attention from regulatory institutions.

\section{Acknowledgements}

This study was funded by the European Union, the Région Réunion, the Conseil Interministériel de l'Outre-Mer (CIOM-RITA) and the Conseil Général of Mayotte (DARTM).

\section{References}

Mbanzibwa DR, Tian YP, Tugume AK, Patil BL, Yadav JS, Bagewadi B, Abarshi MM, Alicai T, Changadeya W, Mkumbira J, Muli MB, Mukasa SB, Tairo F, Baguma Y, Kyamanywa S, Kullaya A, Maruthi MN, Fauquet CM, Valkonen JPT, 2011. Evolution of cassava brown streak diseaseassociated viruses. Journal of General Virology 92, 974-987. http://dx.doi.org/10.1099/Vir.0.026922-0

Monger WA, Alicai T, Ndunguru J, Kinyua ZM, Potts M, Reeder RH, Miano DW, Adams IP, Boonham N, Glover RH, Smith J, 2010. The complete genome sequence of the Tanzanian strain of Cassava brown streak virus and comparison with the Ugandan strain sequence. Archives of Virology 155, 429-433. http://dx.doi.org/10.1007/s00705-009-0581-8

Tamura K, Peterson D, Peterson N, Stecher G, Nei M, Kumar S, 2011. MEGA5: Molecular evolutionary genetics analysis using maximum likelihood, evolutionary distance, and maximum parsimony methods. Molecular Biology and Evolution 28, 2731-2739. http://dx.doi.org/10.1093/molbev/msr121

Winter S, Koerbler M, Stein B, Pietruszka A, Paape M, Butgereitt A, 2010. Analysis of cassava brown streak viruses reveals the presence of distinct virus species causing cassava brown streak disease in East Africa. Journal of General Virology 91, 1365-1372. http://dx.doi.org/10.1099/Vir.0.014688-0

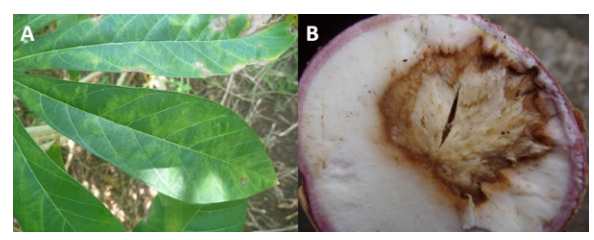

Figure 1

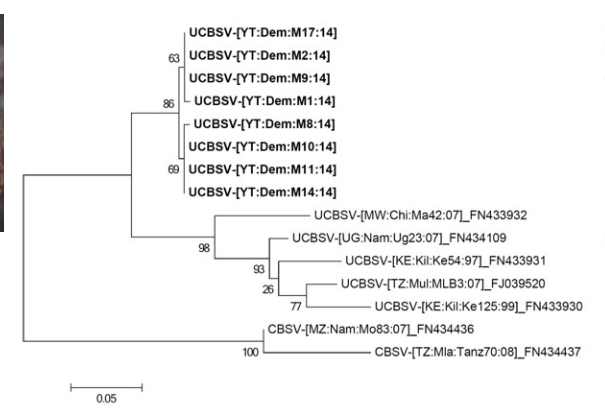

Figure 2



To cite this report: Roux-Cuvelier M, Teyssedre D, Chesneau T, Jeffray C, Massé D, Jade K, Abdoul Karime AL, Hostachy B, Reynaud B, Legg JP, Lett JM, 2014. First report of cassava brown streak disease and associated Ugandan cassava brown streak virus in Mayotte Island. New Disease Reports 30, 28. http://dx.doi.org/10.5197/j.2044-0588.2014.030.028 